\title{
Ultrastructural Characteristics of Aortic Endothelial Cells in Borderline Hypertensive Rats Exposed to Chronic Social Stress
}

\author{
L. OKRUHLICOVÁ ${ }^{1}$, K. DLUGOŠOVÁ ${ }^{1}$, M. MITAŠÍKOVÁ ${ }^{1}$, I. BERNÁTOVÁ ${ }^{2}$ \\ ${ }^{1}$ Institute for Heart Research, Slovak Academy of Sciences, ${ }^{2}$ Institute of Normal and Pathological \\ Physiology, Center of Excellence for Cardiovascular Research, Slovak Academy of Sciences, \\ Bratislava, Slovak Republic
}

Received January 25, 2008

Accepted March 25, 2008

On-line March 28, 2008

\begin{abstract}
Summary
Genetic predisposition and social stress may represent important risk factors in etiology of hypertension associated with endothelial dysfunction. Perturbations of endothelial structural integrity are also critical for the pathogenesis of vascular diseases. We examined effect of chronic social stress on structure of aortic endothelium in borderline hypertensive (BHR) and normotensive Wistar rats. Male BHR - offspring of Wistar mothers and SHR fathers and age-matched $W$ were exposed to 6-week crowding stress ( 5 rats/cage, $200 \mathrm{~cm}^{2} /$ rat). Aortic tissue was processed for electron microscopy and NO synthase activity measurement. Crowding stress significantly increased blood pressure in BHR compared to basal values $(140 \pm 3 \mathrm{~mm} \mathrm{Hg}$ vs. $130 \pm 3 \mathrm{~mm} \mathrm{Hg}, \mathrm{p}<0.05$ ) and reduced enzyme activity by $37 \%$ $(p<0.01)$ in the aorta of BHR. Local slight structural alterations of endothelium were found in non-stressed BHR $(p<0.001)$ when compared with Wistar rats. Chronic stress caused marked $(p<0.005)$ subcellular injury of endothelial cells in aorta of BHR characterized by mitochondrial damage, presence of vacuoles, increased number of lysosomes, Weibel-Palade bodies, changes of intercellular connections and local disruption of endothelium, while only slight changes were seen in Wistar rats. Results suggest increased sensitivity of aortic endothelium of BHR to chronic crowding that may contribute to acceleration of arterial dysfunction.
\end{abstract}

\section{Key words}

Social Stress • Hypertension • Endothelium • Ultrastructure • Rat

\section{Corresponding author}

L. Okruhlicová, Institute for Heart Research, Slovak Academy of Sciences, Dúbravská cesta 9, P.O. Box 104, 84005 Bratislava, Slovak Republic. Fax: + 42125477 6637. E-mail: usrdokru@savba.sk

\section{Introduction}

It is now apparent that endothelial dysfunction referring mainly to impaired NO-dependent vasodilatation precedes clinical symptoms of cardio-vascular disease. Besides, endothelial dysfunction is also accompanied with a microscopically visible cell injury as well as disruption of endothelial barrier lining. These structural alterations are implicated as important pathogenic factors contributing to vascular disease states as they affect the permeability of endothelium, allow the passage of circulating blood cells, macromolecules and inflammatory fluid from blood stream to the underlying tissues (Vallet 2003).

Hypertension is a major risk factor of cardiovascular diseases associated with endothelial dysfunction. Structural alterations of endothelium in vessels observed in hypertensive animals (Kristek et al. 1997, Okruhlicová et al. 2000, 2005, Tribulová et al. 2000) indicated their potential contribution to the development or maintenance of the high blood pressure. Hypertension is multifactorial disease, in many cases resulting from complex interaction of genetic and social factors. The use of chronic psychosocial stress in borderline hypertensive rats (BHR) resulted in the development of hypertension, heart hypertrophy and significant cardiac pathology (Lawler et al. 1981). Psychosocial stress is associated with cardiovascular alterations like endothelial dysfunction, inflammation, metabolic and hematological abnormalities, and increased activity of sympathetic nervous system and renin-angiotensin-aldosterone system (McCarty and Gold 1996, Esch et al. 2002). In addition, it was demonstrated in our previous study that altered vascular NO synthesis 
might also be involved in chronic social stress-induced changes in vascular function and blood pressure in adult borderline hypertensive rats (Bernátová and Csizmadiová 2006).

Although there is some evidence from clinical and experimental studies indicating the impairment of the endothelium-dependent relaxation in hypertension (Török et al. 2006) and chronic stress (Sherwood et al. 1999), there is no available information about the fine structure of endothelium in borderline hypertension exposed to chronic stress. Therefore, we studied the effect of psychosocial stress on endothelial structural integrity of aorta of rats with genetic predisposition to hypertension.

\section{Methods}

Animals

BHR used in the study were born in our certified animal facility as $F_{1}$ offspring of normotensive (Wistar) dams and spontaneously hypertensive sires. All animals BHR and Wistar were housed at $22-24{ }^{\circ} \mathrm{C}$ on a $12: 12-\mathrm{h}$ dark-light cycle (07.00-19.00 lights on) and maintained on a pellet diet and tap water ad libitum. After weaning (25th day), male rats were kept in groups of 4 rats per cage $\left(35 / 55 / 20 \mathrm{~cm}, 480 \mathrm{~cm}^{2} / \mathrm{rat}\right)$. The investigation conforms to the Guide for the Care and Use of Laboratory Animals published by the US National Institutes of Health (NIH Publication NO. 85-23, revised 1996).

\section{Stress model}

Adult male rats, 15 weeks old, were randomly divided into two groups. Control normotensive and borderline hypertensive rats were kept in groups of 4 rats/cage $\left(35 / 55 / 20 \mathrm{~cm}, 480 \mathrm{~cm}^{2} /\right.$ rat $)$. Rats exposed to crowding stress were kept in groups 5 rats/cage (25/49/15 $\mathrm{cm}$ ), where their living space was reduced to $200 \mathrm{~cm}^{2} / \mathrm{rat}$, for 6 weeks (Bernátová and Csizmadiová 2006).

\section{Blood pressure measurement}

Two weeks before the experiment, the rats were handled and accustomed to the procedure of blood pressure recording, using non-invasive tail-cuff plethysmography. Blood pressure was determined at the beginning and at the end of experiment after 6 weeks.

\section{NO synthase activity}

NO synthase activity was determined in crude homogenates of aorta by determination of $\left[{ }^{3} \mathrm{H}\right]-\mathrm{L}$ citrulline formation from $\left[{ }^{3} \mathrm{H}\right]$-L-arginine (Amersham,
UK), as described previously (Bernátová et al. 2002).

\section{Transmission electron microscopy}

For electron microscopic examination the heart was retrogradely fixed via thoracic aorta with $2.5 \%$ glutaraldehyde in $100 \mathrm{mmol} / \mathrm{l}$ cacodylate buffer ( $\mathrm{pH} \mathrm{7.4)}$. Thoracic aorta was cut into $3 \mathrm{~mm}$ long rings and additionally fixed by immersing in $2.5 \%$ glutaraldehyde for $3 \mathrm{~h}$ at $4{ }^{\circ} \mathrm{C}$. After washing in cacodylate buffer, the tissue was postfixed in $1 \% \mathrm{OsO}_{4}$, dehydrated via ethanol series, infiltrated with propylene oxide and embedded in Epon 812. Ultrathin sections cut on ultramicrotome LKB Huxley (London, Great Britain) were counterstained with uranyl acetate and lead citrate and examined in electron microscope Tesla 500 (Brno, Czech Republic).

\section{Statistical analysis}

For the quantitative scoring, the electron micrographs of aortic endothelium were given a random number and scored blindly by three people. The pictures were scored from zero to three based on the level of structural changes seen in mitochondria, nucleus, vacuoles, lysosomes, Weibel-Palade bodies and intercellular connections. Score "zero" represents normal cell architecture, "one" slight change in cell structure, "two" moderate, and "three" represents severe injury of cell structure. The three independent scores were averaged together for each slide.

Differences were assigned between individual groups using Student's t-test. Values were considered to be different significantly when $\mathrm{p}<0.05$. All data are expressed as mean $\pm \mathrm{SEM}$.

\section{Results}

\section{Blood pressure measurement}

The chronic stress did not affect the blood pressure in stressed normotensive Wistar rats when compared with non-stressed rats $(111 \pm 2 \mathrm{~mm} \mathrm{Hg}$ vs. $113 \pm 2 \mathrm{~mm} \mathrm{Hg}$ ). On the other hand, blood pressure was significantly increased in BHR exposed to chronic crowding compared to basal values $(130 \pm 2 \mathrm{~mm} \mathrm{Hg}$ vs. $140 \pm 3 \mathrm{~mm} \mathrm{Hg}, \mathrm{p}<0.05)$.

\section{NO synthase activity}

The NO synthase activity was $7.75 \pm 0.80$ $\mathrm{pmol} / \mathrm{min} / \mathrm{mg}$ in aorta of control BHR. Chronic stress reduced the enzyme activity in stressed BHR $(3.32 \pm 0.52$ $\mathrm{pmol} / \mathrm{min} / \mathrm{mg}, \mathrm{p}<0.01)$. Crowding stress did not affect the 
Tab. 1. Quantitative score of subcellular alterations in endothelial cells of the aorta.

\begin{tabular}{lll}
\hline & Control & Stress \\
\hline$W$ & $0.23 \pm 0.01$ & $0.93 \pm 0.02$ \\
$B H R$ & $1.06 \pm 0.02^{+}$ & $2.06 \pm 0.02 *$ \\
\hline
\end{tabular}

${ }^{*} \mathrm{p}<0.005$, BHR vs. BHRs; ${ }^{+} \mathrm{p}<0.001, \mathrm{~W}$ vs. BHR. W - Wistar rats, BHR - borderline hypertensive rats. Subcellular alterations included changes in mitochondria, nucleus, vacuoles, lysosomes, Weibel-Palade bodies and intercellular connections.

NO synthase activity in aorta of Wistar rats compared to non-stressed rats $(5.25 \pm 0.44 \mathrm{pmol} / \mathrm{min} / \mathrm{mg}$ vs. $5.22 \pm 0.79$ $\mathrm{pmol} / \mathrm{min} / \mathrm{mg}$ ).

\section{Transmission electron analysis}

The electron microscopic examination showed classic architecture of aortic endothelial cells in control normotensive Wistar rats and in BHR. However, in BHR the endothelial cells locally displayed slight till moderate subcellular injury (Fig. 1) manifested by heterogeneous density of cell cytoplasm, presence of vacuoles, increased amount of lysosomes and Weibel-Palade bodies and electronlucent chromatin. Intercellular connections contained interdigitating complexes, overlapping clefts and end-to-end connections containing gap junctions and occasionally irregularly widened tight junctions.

The chronic stress resulted in structural alteration of endothelial cells of aorta of Wistar rats resembling those in non-stressed BHR (Fig. 2). Ultrastructural analysis of aortic endothelial cells of stressed BHR showed more severe subcellular injury compared to control BHR (Fig. 3). The cells were edematous, contained injured mitochondria, numerous vacuoles, and electronlucent chromatin. The integrity of the endothelial lining was locally destroyed. Quantitative scoring of subcellular alterations of endothelial cells is shown in Table 1. In addition, smooth muscle cells located in subendothelial media also locally displayed subcellular injury (Fig. 3).

\section{Discussion}

The vascular endothelium is an active, dynamic tissue that controls many important functions, including regulation of vascular tone, maintenance of blood circulation, fluidity, coagulation, and inflammatory responses (Galley and Webster 2004). Therefore, the impairment of endothelial structure may contribute to
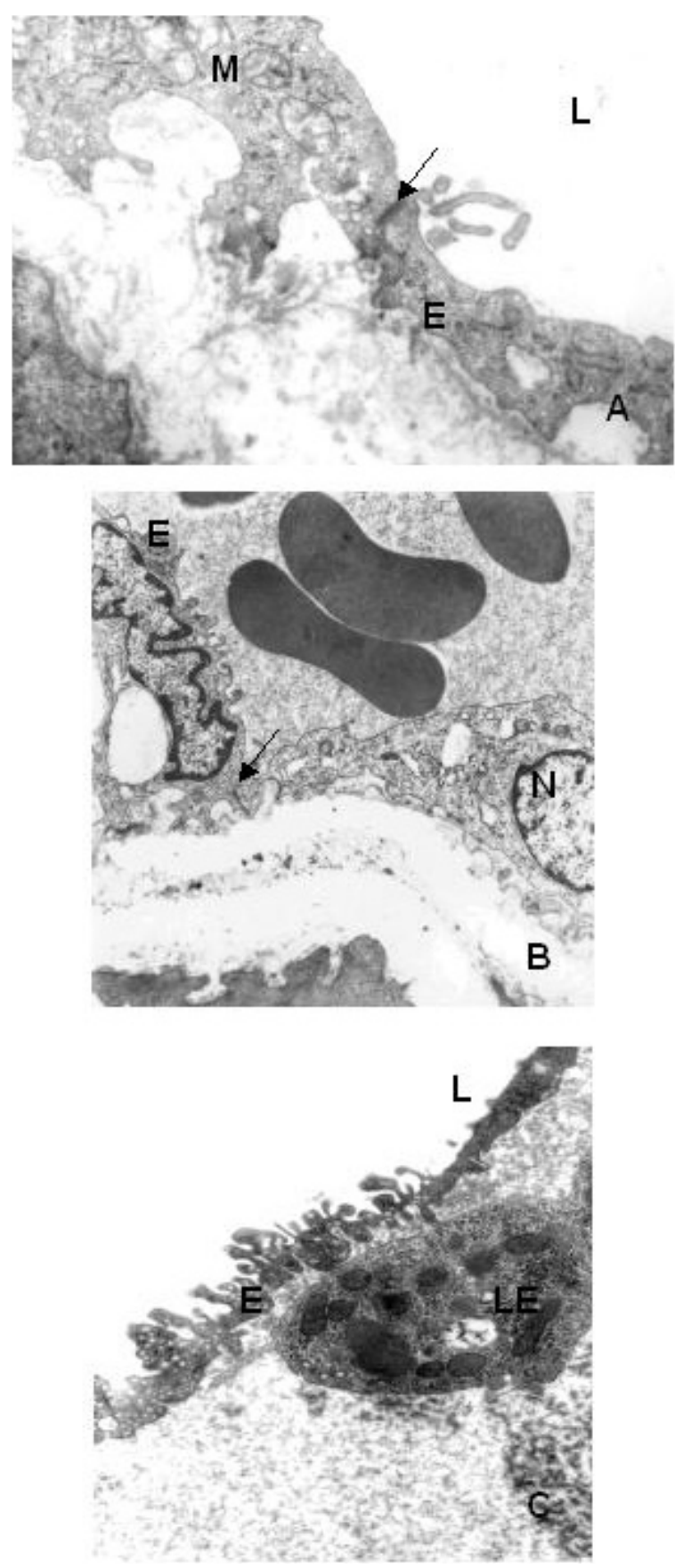

Fig. 1. Electron micrographs showing subcellular injury of aortic endothelium of control borderline hypertensive rats. Magnification: A x16 000, B x15 000, C x11 000.

endothelial dysfunction that may initiate or contribute to changes in cell adhesion, lipid deposition, and other early steps leading to vascular diseases.

In the present study we have examined the effect of chronic social stress on the structure of aortic endothelial cells of rats with a genetic predisposition to hypertension. The most important finding of this study was that chronic crowding caused marked subcellular injury of endothelium in BHR and also slight one in 



Fig. 2. Chronic stress-induced subcellular injury of aortic endothelium and smooth muscle cells in borderline hypertensive rats. Magnification: A x12 000, B x10 000, C x10 000, D x14 000.

stressed normotensive Wistar rats. Important is also the fact that even borderline hypertension was associated with focal subcellular damage of endothelial cells.

In our experiments we used a less traditional model of borderline hypertension with a normotensive mother and SHR father to prevent any effect of different maternal behavior and gestation environment of the hypertensive dams on blood pressure of their offspring (Woodworth et al. 1990, Porter et al. 2004). The model of borderline hypertension is appropriate for the investigation of stress-cardiovascular interactions since BHR are more sensitive to behavioral stress than normotensive and they do not develop age-dependent hypertension, while SHR do (Lawler et al. 1981). Basal blood pressure of BHR in the present work was in the range $130-150 \mathrm{~mm} \mathrm{Hg}$ and was comparable to that reported by Woodworth et al. (1990). Impaired endothelial-dependent vascular relaxation was observed 

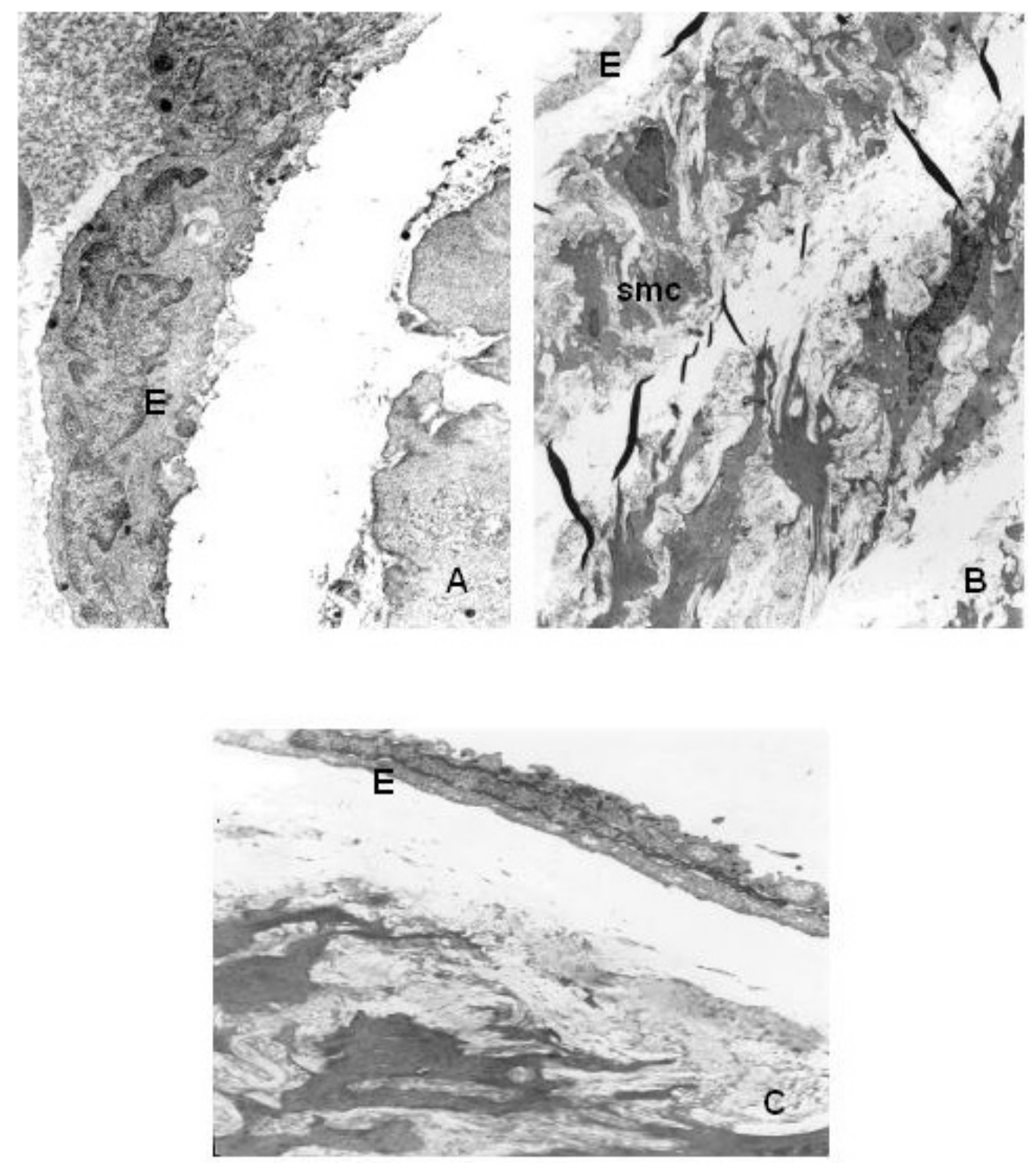

Fig. 3. Electron micrographs of endothelium and smooth muscle cells in control Wistar rats (A, B). Crowding stress-induced subcellular injury of aortic endothelium in stressed Wistar rats. Magnification: A x15 000, B x10 000, C x10 000. E - endothelium, L - lumen, LE subendothelial leukocyte, Ly - lysosomes, $\mathrm{M}$ - mitochondria, $\mathrm{N}$ - nucleus, arrow - intercellular connection, arrow head - endothelial lining disruption, smc - smooth muscle cell, $v$ - vacuoles.

in offspring of hypertensive patients (Esch et al. 2002) and animals as well (Liu et al. 2002). Our results showing local damage of endothelial cells of the aorta of control BHR indicated that it might affect endothelial integrity and permeability and activate inflammatory processes, which can initiate atherogenesis in a vessel (Schächinger and Zeiher 2002). Since no such prominent structural alterations were demonstrated in the aortic endothelium of control Wistar rats, it is possible to eliminate the effect of processing on the cell structure in BHR. It can indicate genetic origin of alterations due to interaction of some peculiar genetic network present in the hypertensive subject including related genes of the renin-angiotensin- aldosterone system (Corvol et al. 1999), angiotensinconverting enzyme (Fornage et al. 1998), activation of extracellular dual phosphorylated (Thr202/tyr204) extracellular-signal activated protein kinases (ERK) (Barančík et al. 2007) as well as activation of sympathetic nervous system.

The endothelial cells display the remarkable heterogeneity in the vascular tree (Garlanda and Dejana 1997). Despite that several studies demonstrated similar structural injury of endothelial monolayer in resistant and conduit vessels of hypertensive animals (Kristek et al. 1997, Tribulová et al. 2000, Okruhlicová et al. 2005), indicating pronounced sensitivity of endothelium to 
increased blood pressure. Ultrastructural changes of endothelium were also observed in NO-deficient hypertension (Okruhlicová et al. 2000, Tribulová et al. 2000) accompanied with structural remodeling of vessel wall (Kristek et al. 1996, Cebová et al. 2006), associated with reduced NO production per se rather than with hypertension (Holécyová et al. 1996) and with attenuated vasodilatation.

Social chronic stress in a modern world represents an important risk factor for development of the cardiovascular disease. Its deleterious effects depend on the critical period of exposure, duration and type - as they all may alter functions of the basic autoregulatory stress response components: the hypothalamic-pituitaryadrenal axis and the sympathoadrenal medullar system activating renin-angiotensin-aldosterone system and sympathetic nervous system (McCarty and Gold 1996, Esch et al. 2002). Crowding evokes social stress reactions with prominent psychosocial components mimicking emotional state alterations (Bugajski 1999). Although crowding is a relatively weak stressor, chronic exposure may induce behavioral changes (Dubovický et al. 1999) and may affect the function of cardiovascular system, especially in individuals exhibiting higher responses to stressful conditions including genetic predisposition to hypertension. Our results demonstrated reduced activity of NO synthase in the aorta of stressed BHR. Ultrastructural injury of endothelial cell mitochondria of stressed BHR suggests that NO production may also be associated with an imbalance of defense antioxidative stress system that contributes to the reduction of NO in the cells. In addition, mitochondrial injury indicates also changes in intracellular ATP levels. The endothelial dysfunction is also accompanied with inflammation and procoagulation processes. In endothelial cells of stressed BHR we observed increased amount of Weibel-Palade bodies producing von Willenbrand factor that is known as a marker of adhesive, coagulative and thrombotic processes (Wannamethee et al. 2006); furthermore there were seen vacuoles and lysosomes representing structural markers of cell degradation processes, and altered intercellular connections providing functional coordination and communication between endothelial cells (Isakson et al. 2006). All these subcellular alterations may indicate considerable changes in adhesive, and permeable properties of the endothelium that can facilitate the transmigration of leukocytes into subendothelial area and accelerate progression of inflammation and atherosclerotic injury.

In conclusion: our results indicate that borderline hypertension is associated with the subcellular injury of aortic endothelial cells that may contribute to higher sensitivity of the endothelium to chronic stress and accelerate the arterial dysfunction.

\section{Conflict of Interest}

There is no conflict of interest.

\section{Acknowledgements}

This study was supported by Science and Technology Assistance Agency APVT-51-018004 and APVV-51059505 and VEGA 2/4156/25, 2/5021/25. We express our thanks to A. Macsaliová, I. Macková, Y. Hanáčková and J. Pet'ová for their skilful laboratory and technical assistance.

\section{References}

BARANČÍK M, IVANOVÁ M, RAVINGEROVÁ T, BERNÁTOVÁ I: The role of protein kinases in responses to chronic social stress in rat hearts. Physiol Res 56: 4P, 2007.

BERNÁTOVÁ I, CSIZMADIOVÁ Z: Effect of chronic social stress on nitric oxide synthesis and vascular function in rats with family history of hypertension. Life Sci 78: 1726-1732, 2006.

BERNÁTOVÁ I, PECHÁŇOVÁ O, BABÁL P, KYSELA S, ŠTVRTINA S, ANDRIANTSITOHAINA R: Wine polyphenols improve cardiovascular remodeling and vascular function in NO-deficient hypertension. Am J Physiol 282: H942-H948, 2002.

BUGAJSKI J: Social stress adapts signaling pathways involved in stimulation of the hypothalamic-pituitary-adrenal axis. J Physiol Pharmacol 50: 367-379, 1999.

CEBOVÁ M, KRISTEK F, KUNEŠ J: Differential remodeling of carotid artery in spontaneously hypertensive and hereditary hypertriglyceridemic rats. Physiol Res 55 (Suppl 1): S81-S87, 2006.

CORVOL P, PERSU A, GIMENEZ-ROQUEPLO AP, JEUNEMAITRE X: Seven lessons from two candidate genes in human essential hypertension: angiotensinogen and epithelial sodium channel. Hypertension 33: 1324-1331, 1999. 
DUBOVICKÝ M, ŠKULTÉTYOVÁ I, JEŽOVÁ D: Neonatal stress alters habituation of exploratory behavior in adult male but not female rats. Pharmacol Biochem Behav 64: 681-686, 1999.

ESCH T, STEFANO GB, FRICCHIONE GL, BENSON H: Stress in cardiovascular diseases. Med Sci Monit 8: RA93RA101, 2002.

FORNAGE M, AMOS CI, KARDIA S, SING CF, TUMER ST: Variation in the region of the angiotensin-converting enzyme gene influences interindividual differences in blood pressure levels in young white males. Circulation 97: 1773-1779, 1998.

GALLEY HF, WEBSTER NR: Physiology of the endothelium. Br J Anaesth 93: 105-113, 2004.

GARLANDA C, DEJANA E: Heterogeneity of endothelial cells. Specific markers. Arterioscler Thromb Vasc Biol 17: 1193-1202, 1997.

HOLÉCYOVÁ A, TŐRÖK J, BERNÁTOVÁ I, PECHÁŇOVÁ O: Restriction of nitric oxide rather than elevated blood pressure is responsible for alterations of vascular responses in nitric oxide-deficient hypertension. Physiol Res 45: 317-321, 1996.

ISAKSON BE, DAMON DN, DAY KH, LIAO Y, DULLING BR: Connexin 40 and connexin 43 in mouse aortic endothelium: evidence for coordinated regulation. Am J Physiol 290: H1199-H1205, 2006.

KRISTEK F, GEROVÁ M, DEVÁT L, VARGA I: Remodelling of septal branch of coronary artery and carotid artery in L-NAME treated rats. Physiol Res 45: 329-333, 1996.

KRISTEK F, EDELSTEINOVÁ S, SEBOKOVÁ E, KYSELOVIČ J, KLIMEŠ I. Structural changes in the aorta of the hereditary hypertriglyceridemic rat. Ann N Y Acad Sci 827: 514-520, 1997.

LAWLER JE, BAKER GF, HUBBARD JW, SCHAUB RG: Effects of stress on blood pressure and cardiac pathology in rats with borderline hypertension. Hypertension 3: 496-505, 1981.

LIU H, LEDINGHAM JM, MULLANEY I, LAVERTY R: Endothelial function in mesenteric resistant arteries from the genetically hypertensive rat. Clin Exp Pharmacol Physiol 29: 405-411, 2002.

MCCARTY R, GOLD PE: Catecholamines, stress, and disease: a psychobiological perspective. Psychosom Med 58: 590-597, 1996.

OKRUHLICOVÁ L', TRIBULOVÁ N, BERNÁTOVÁ I, PECHÁŇOVÁ O. Induction of angiogenesis in NO-deficient rat heart. Physiol Res 49: 71-76, 2000.

OKRUHLICOVÁ L', TRIBULOVÁ N, WEISMANN P, SOTNÍKOVÁ R: Ultrastructure and histochemistry of rat myocardial capillary endothelial cells in response to diabetes and hypertension. Cell Res 15: 520-526, 2005.

PORTER JP, PHILLIPS A, RICH J, WRIGHT D: Effect of chronic stress on the cardiac baroreflex in the post-weanling rat. Life Sci 75: 1595-1607, 2004.

SCHÄCHINGER V, ZEIHER AM: Atherogenesis - recent insights into basic mechanisms and their clinical impact. Nephrol Dial Transplant 17: 2055-2064, 2002.

SHERWOOD A, JOHNSON K, BLUMENTHAL JA, HINDERLITER AL: Endothelial function and hemodynamic responses during mental stress. Psychosom Med 61: 365-370, 1999.

TŐRŐK J, KOPRDOVÁ R, CEBOVÁ M, KUNEŠ J, KRISTEK F: Functional and structural pattern of arterial responses in hereditary hypertriglyceridemic and spontaneously hypertensive rats in early stage experimental hypertension. Physiol Res 55 (Suppl 1): S65-71, 2006.

TRIBULOVÁ N, OKRUHLICOVÁ L', BERNÁTOVÁ I, PECHÁŇOVÁ O: Chronic disturbances in NO production results in histochemical and subcellular alterations in the rat heart. Physiol Res 49: 77-88, 2000.

VALLET B. Bench-to-bedside review. Endothelial cell dysfunction in severe sepsis: a role in organ dysfunction? Crit Care 7: 130-138, 2003.

WANNAMETHEE SG, SHAPER AG, LOWE GD, LENNON L, RUMLEY A, WHINCUP PH: Renal function and cardiovascular mortality in elderly men: the role of inflammation, procoagulant, and endothelial biomarkers. Eur Heart J 24: 2975-2981, 2006.

WOODWORTH CH, KNARDAHL S, SANDERS BJ, KIRBY RF, JOHNSON AK: Dam strain affects cardiovascular reactivity to acute stress in BHR. Physiol Behav 47: 139-144, 1990. 